
\title{
25 Research Soure \\ The effect of COVID-19 pandemic on air quality caused by traffic in Istanbul
}

\section{Songül KASKUN ( $\square$ songulkaskun@karabuk.edu.tr)}

Department of Environmental Engineering, Engineering Faculty, Karabuk University, 78050 Karabuk/Turkey

\section{Kadir ULUTAŞ}

Department of Environmental Engineering, Engineering Faculty, Karabuk University, 78050 Karabuk/Turkey

Keywords: COVID-19, PM10, NO2, air quality

Posted Date: May 22nd, 2020

DOl: https://doi.org/10.21203/rs.3.rs-28880/v1

License: (a) (i) This work is licensed under a Creative Commons Attribution 4.0 International License. Read Full License 


\section{Abstract}

The COVID-19 pandemic has become global public health concern and the first death due to COVID-19 in Turkey occurred on 16 March 2020. Therefore, the Turkish governments took some precautions such as curfew, travel restriction, social isolation and shut down the schools and the universities within the scope of the fight of COVID-19. These precautions may cause a decrease in mobility, which in turn expectation to decrease in traffic-related emissions. In this study, the change in the amount of $\mathrm{PM}_{10}$ and $\mathrm{NO}_{2}$ pollutants were evaluated by dividing them in two periods before and after the virus in 2016 and 2020 . Traffic-induced $\mathrm{PM}_{10}$ and $\mathrm{NO}_{2}$ concentrations were monitored at 4 stations located close to road traffic in Istanbul. As a result of the study, it was observed that there was no significant difference in $\mathrm{PM}_{10}$ concentration, however $\mathrm{NO}_{2}$ concentrations decreased by 11.8 percent in the after-virus period.

\section{Highlights}

- The effect of COVID-19 pandemic on traffic induced-PM $\mathrm{M}_{10}$ and $\mathrm{NO}_{2}$ concentrations in Istanbul was studied.

- The pollutants concentrations were examined using the SPSS program as two independent groups during the BV and the AV.

- There was no effect of precautions taken for COVID-19 on PM $_{10}$ concentrations between the BV and the AV.

- The significant difference of $\mathrm{NO}_{2}$ concentrations was observed statistically between the $\mathrm{BV}$ and the AV.

\section{Introduction}

A virus from the coronavirus family was detected on people in Wuhan, China in December 2019. This corona virus type has spread to Asia-Pacific region countries, North America and Europe within one month (Fig.1) [1]. A disease caused by this new coronavirus was temporarily called the 2019 new coronavirus (2019-nCoV) disease before 11 February 2020. The disease was renamed as COVID-19 by the World Health Organization, and the virus was classified as SARS-CoV-2 by the International Committee on Taxonomy of Viruses (ICTV) on February 11, 2020.

The virus, causing COVID-19 infectious in humans, has become a global epidemic by now. It was reported that 2,397,216 people worldwide were diagnosed with COVID-19 and 162,956 people died from this disease, while 95,591 people were put to Covid-19 diagnosis and 2017 people died in Turkey until 21 April 2020 (Fig.2) [1-2]. 
There are different approaches to prevent COVID-19 pandemic in different countries and prevent the further spread of this disease. Some of the more common approaches have seen governments COVID-19 recommendations on stay home for part or all of the country, while others have acted to limit all nonessential movement, curfew, shot down the schools cafes and universities, etc. In Turkey, curfew is only applied to those under the age of 20 or over 65. Also, the curfew between 11-12.04.2020 and 1819.04.2020 was applied to all citizens in 30 major cities and Zonguldak province in Turkey.

Due to COVID-19 outbreak, the mobility has decreased considerably, a parallel decrease can be observed in air pollution from fossil fuel burning vehicles. Since the fossil fuels supply most of the energy requirements, especially the use of gasoline and diesel fuel in transportation, constitutes the basis of air pollution [3-5]. It was stated at the 1st Global Air Pollution and Health Conference, which was organized for the first time in the world in 2018, that air pollution caused more than 7 million people died prematurely every year [6]. These situations reveal a strong relationship between air pollution and health. Moreover, air pollution can weaken the immune system, causes people to be easily infected from the virus [7-9]. Therefore, increased air pollution may trigger an increase in the number of Covid-19 patients.

Air pollution parameters are measured in four categories as urban, rural, traffic and industry throughout the world. Particulate matter $\left(\mathrm{PM}_{10}\right.$ and $\left.\mathrm{PM}_{2.5}\right)$, Nitrogen dioxide $\left(\mathrm{NO}_{2}\right), \mathrm{NOx}, \mathrm{O}_{3}$ and $\mathrm{CO}$ are mainly measured in accordance with international standards. The size of the particulate matter (PM) effects on human health and its processes in the atmosphere varies [10]. While large particles can be kept mostly in the upper respiratory tract, thin and ultra-thin particles can reach the lower respiratory tract, lungs and alveolus [11]. Many studies on atmospheric particulate matter show that prolonged exposure to particulate matter of different sizes such as $\mathrm{PM}_{2.5}, \mathrm{PM}_{10}$ and $\mathrm{PM}_{1}$ has negative effects on human health and causes an increase in mortality rates [12-16]. These effects vary depending on the chemical composition of $\mathrm{PM}_{10}$. Chemical components of $\mathrm{PM}_{10}$ include dissolved salts, metals, organic compounds, carbon products, and acids. The negative health effects of chemical components are caused by the composition of many compounds [17]. Potential health effects of pollutants in $\mathrm{PM}_{10}$ content depend on many factors such as toxicity, bioavailability and total pollutant content of $\mathrm{PM}_{10}$. [18]. Especially, the exposure to $\mathrm{PM}_{10}$ concentrations may cause various chronic diseases such as lung cancer [19] asthma [20-21] and kidney disorders [22]. Furthermore, trace elements such as arsenic, beryllium, cadmium, chromium and nickel in the content of $\mathrm{PM}_{10}$ are classified as carcinogens by the International Cancer Research Center (IARC). On the other hand, non-cancer negative health effects of many other trace elements have also been revealed [23]. It has been demonstrated sulphate, nitrate, organic and elemental carbon components, permanent organic pollutants such as PAH and PCBs which leads serious health effects such as cancer on human health, cardiovascular and respiratory diseases can be found in the content of anthropogenic $\mathrm{PM}_{10}$ [24-25].

$\mathrm{NO}_{2}$, another most important air pollutants, reacts with volatile organic components within a photochemical reaction, forming ozone which is one of the secondary air pollutants [26]. The main sources of $\mathrm{NO}_{2}$ are road traffic, power generation, industries and residential heating. $\mathrm{NO}_{2}$ may cause lung 
damages because of its limited solubility and high oxidative potential but it is not possible to find out whether this is due to $\mathrm{NO}_{2}$ itself or to the secondary pollutants [27-28]. So, exposures to high concentrations of $\mathrm{NO}_{2}$ may promote severe diseases such as colds, flu and bronchitis. Moreover, $\mathrm{NO}_{2}$ is related with mortality from cardiovascular, ischemic heart, cerebrovascular, respiratory disease, and cancer [29-32]. According to the recent research, exposure to high concentration of $\mathrm{NO}_{2}$ may increase the death from COVID-19, especially in cities with high air pollution [33].

In this study, the effects of COVID-19 epidemic on air pollution in Istanbul which has a population of over 15 million, were examined. The difference in $\mathrm{PM}_{10}$ and $\mathrm{NO}_{2}$ concentrations were monitored by dividing them in two periods: before and after the virus in 2016 and 2020. Traffic-induced $\mathrm{PM}_{10}$ and $\mathrm{NO}_{2}$ concentrations were evaluated at all traffic stations in Istanbul. It is also thought that gas emission from transportation will decrease due to the decrease in mobility rate.

\section{Materials And Methods}

In the study, the effects of the precautions to minimise negative effects of COVID-19 pandemic on air quality were assessed. $\mathrm{PM}_{10}$ and $\mathrm{NO}_{2}$ concentrations were monitored 79 days from 4 air quality monitoring station in Istanbul between 01.02-19.04 in 2016-2020. This period was evaluated based on all years in the two periods: before virus (BV) for 01.02-15.03 and after virus (AV) for 16.03-14.04 considering of precaution taken for covid-19. Graphic models were developed to show $\mathrm{PM}_{10}$ and $\mathrm{NO}_{2}$ concentrations which were provided by Ministry of Environment and Urbanization/Turkey National Air Quality Monitoring Network [34]. The assessment was made according to the data of 4 stations Uskudar ( $\left.41^{\circ} 01^{\prime} 37^{\prime \prime}-29^{\circ} 01^{\prime} 29^{\prime \prime}\right)$, Umraniye ( $\left.41^{\circ} 01^{\prime} 27^{\prime \prime}-29^{\circ} 05^{\prime} 59^{\prime \prime}\right)$, Mecidiyekoy ( $\left.41^{\circ} 03^{\prime} 57^{\prime \prime}, 28^{\circ} 59^{\prime} 40^{\prime \prime}\right)$ and Sirinevler ( $\left.41^{\circ} 00^{\prime} 08^{\prime \prime}, 28^{\circ} 50^{\prime} 19^{\prime \prime}\right)$ stations having high potential traffic and human density, in the traffic category in Istanbul. TURKSTAT's 2019 data shows that, the total population is 1,519,267 and the number of motor vehicles is 4,187,776 in 2019 in İstanbul [35].

$\mathrm{PM}_{10}, \mathrm{NO}_{2}$ concentrations and temperature were calculated daily and monthly as a result of hourly measurements at the stations. The $\mathrm{PM}_{10}$ and $\mathrm{NO}_{2}$ concentrations in the $\mathrm{AV}$ and in the $\mathrm{BV}$ were evaluated in the study period. Also, general trends of the pollutants in the study period were assessed for 20162020. Within the scope of European Union harmonization process, evaluation of air quality data is carried out according to the provisions of Regulation on Air Quality Assessment and Management and $\mathrm{NO}_{2}$ and $\mathrm{PM}_{10}$ have become compatible with EU limit concentrations, since 2019. According to the regulation which was published by the Ministry of Environment and Urbanization in 2008, the limit concentration for $\mathrm{NO}_{2}$ was determined as $250 \mu \mathrm{g} / \mathrm{m}^{3}$ hourly and $40 \mu \mathrm{g} / \mathrm{m}^{3}$ annually (with 18 exceedances permitted per year). Also, $\mathrm{PM}_{10}$ concentration was set as $40 \mu \mathrm{g} / \mathrm{m}^{3}$ annually (with 35 exceedances permitted per year) and $50 \mu \mathrm{g} / \mathrm{m}^{3}$ daily in order to protect human health. The concentrations of the pollutants were evaluated according to EU Directive and Regulation on Air Quality Assessment and Management (RAQAM). The measurements were made by air quality monitoring stations, according to RAQAM, the determination of 
mass concentrations, in the outdoor air for $\mathrm{NO}_{2}$ analyse, was made with chemi-luminescence as ISO 7996 the reference method. EN 12341 "Air Quality-PM10 fraction determination method of suspended particulate matter" was used as reference method for measurement of $\mathrm{PM}_{10}$. The measurement principle is based on collecting the $\mathrm{PM}_{10}$ fraction of the particulate matter in the medium on the filter and gravimetric mass determination.

Then, the changes on the pollutants during the BV and the AV were examined for the statistical analysis using the Statistical package for the social sciences, (SPSS) program as two independent groups. IBM SPSS Statistics 22 (SPSS IBM, Turkey) programs were used for statistical analysis to evaluate the data in the study. Descriptive statistical methods (mean, standard deviation, median, minimum, maximum) were used for the data assessment. The suitability of quantitative data for normal distribution was tested within Kolmogorov-Smirnov, Shapiro-Wilk test and graphical evaluations. Mann Whitney $U$ test was used to compare two groups of non-normally distributed data. Also, Kruskal Wallis test was used for comparisons of three or more groups that did not show normal distribution, and Bonferroni-Dunn test was used for binary comparisons. Significance was evaluated at the level of $p<0.05$.

\section{Result And Discussion}

The average $\mathrm{PM}_{10}$ concentration was $36.71 \pm 19.72 \mu \mathrm{g} / \mathrm{m}^{3}$ during the study period in Uskudar station in 2020 (Fig.4). The average $\mathrm{PM}_{10}$ concentrations were $40.18 \pm 18.43 \mu \mathrm{g} / \mathrm{m}^{3}$ and $31.56 \pm 20.75 \mu \mathrm{g} / \mathrm{m}^{3}$ during the $B V$ and the $A V$ respectively. $\mathrm{PM}_{10}$ concentration during the $A V$ was lower than the $B V$ for all years except 2016 and 2018. Also, the minimum $\mathrm{PM}_{10}$ concentration was obtained in 2020. Although the minimum temperature was seen, which in turn expectation of high $\mathrm{PM}_{10}$ concentration, the minimum $\mathrm{PM}_{10}$ concentration was observed during the $\mathrm{AV}$ in 2020. Thanks to precautions taken for COVID-19 epidemic, there was statistically significant difference for $\mathrm{PM}_{10}$ concentration between the $\mathrm{BV}$ and the AV in 2020, statistically ( $p=0.019 ; p<0.05)$ (Table 1$)$.

The avarage $\mathrm{PM}_{10}$ concentration was $46.85 \pm 21.32 \mu \mathrm{g} / \mathrm{m}^{3}$ for the study period at Sirinevler station in 2020 (Fig.5). As it was expected, the avarage $\mathrm{PM}_{10}$ concentration during the $\mathrm{AV}\left(45.58 \pm 23.57 \mu \mathrm{g} / \mathrm{m}^{3}\right)$ was lower than the BV $\left(47,85 \pm 19,56 \mu \mathrm{g} / \mathrm{m}^{3}\right)$. Except 2018 , the $\mathrm{PM}_{10}$ concentration during the BV was higher than the $\mathrm{AV}$ for all years. However, the differences between the BV and the AV were not attributed to positive affect on air quality in terms of $\mathrm{PM}_{10}$ concentration. Although 2016 has the lowest value for $\mathrm{PM}_{10}$ concentration, there was no meaningful difference for $\mathrm{PM}_{10}$ concentrations between the $\mathrm{BV}$ and the AV, statistically ( $p=0,388 ; p>0.05)$ (Table 1$)$.

The average $\mathrm{PM}_{10}$ concentration was $57.31 \pm 28.40 \mu \mathrm{g} / \mathrm{m}^{3}$ in the study period and $\mathrm{PM}_{10}$ concentration during the BV $\left(56.25 \pm 20.31 \mu \mathrm{g} / \mathrm{m}^{3}\right)$ and the AV $\left(58.47 \pm 35.55 \mu \mathrm{g} / \mathrm{m}^{3}\right)$ were seen very close to each other at Mecidiyekoy station in 2020 (Fig.6).. Unfortunately, there was no significant difference for $\mathrm{PM}_{10}$ concentrations between the AV and the BV, while expecting the AV to be lower than the BV. This indicates the importance of other emission sources for PM pollutant, such as commercial and institutional 
buildings, household heating, etc. Contrary to expectations it was not seen positive effect of COVID-19 pandemic related to mobility on air quality at Mecidiyekoy station in the study period. Consequently, the statistically significant difference could not be seen for the $\mathrm{PM}_{10}$ concentrations regarding to Mecidiyekoy stations $(p=0,608 ; p>0.05)$ (Table 1$)$ during the BV and the AV.

The average $\mathrm{PM}_{10}$ concentration was $32.35 \pm 13.20 \mu \mathrm{g} / \mathrm{m}^{3}$ at Umraniye station for the study period in 2020 (Fig.7). There was approximately equality for $\mathrm{PM}_{10}$ concentrations between the BV $(32.49 \pm 9.80)$ and the $\mathrm{AV}\left(32.18 \pm 16.56 \mu \mathrm{g} / \mathrm{m}^{3}\right)$ in 2020. Although the $\mathrm{PM}_{10}$ concentration during the $\mathrm{AV}$ was higher than the $B V$ between 2016 and 2018, the $\mathrm{PM}_{10}$ concentrations during the $A V$ were lower than the $B V$ in 2019 and 2020. However, it cannot be seen the positive effect of the prevention taken for COVID-19 pandemic on air quality in the manner of PM10 concentration between the BV and the AV. Hence, there was no statistically significant difference for $\mathrm{PM}_{10}$ concentration during the BV and the $\mathrm{AV}(p=0.395 ; p>0.05)$ (Table 1). Interestingly, for PM10 higher exceedances were recorded during the AV more than the BV only at Umraniye Station in Istanbul.

The average $\mathrm{PM}_{10}$ concentrations of Istanbul, were calculated using the data from Uskudar, Sirinevler, Mecidiyekoy and Umraniye stations, were seen in Fig. 8. The average $\mathrm{PM}_{10}$ concentration was $43.22 \pm 19.76 \mu \mathrm{g} / \mathrm{m}^{3}$ for the study period in İstanbul. There was approximately equality for $\mathrm{PM}_{10}$ concentrations between the BV $\left(43.79 \pm 15.37 \mu \mathrm{g} / \mathrm{m}^{3}\right)$ and the AV $\left(42.50 \pm 24.41 \mu \mathrm{g} / \mathrm{m}^{3}\right)$ in 2020 . Although $\mathrm{PM}_{10}$ concentrations during the $\mathrm{AV}$ was lower than the BV comparing to all years except 2017, there was no statistically significant difference for $\mathrm{PM}_{10}$ concentration between the $B V$ and the $A V(p=0.215$; $p>0.05$ ) (Table 1). Hence, the precaution taken for COVID-19 pandemic on air quality was not effective. This indicates the importance of other emission sources for $\mathrm{PM}_{10}$ pollutant, such as commercial and institutional buildings, household heating, etc.

When considering to all station, it was not seen statistically significant difference according to all stations ( $p>0.05$ ) except Uskudar station ( $p=0.019 ; p<0.05$ ) (Table 3.) for $\mathrm{PM}_{10}$ concentrations between the BV and the AV. Therefore, the binary comparison was made to identify the group that creates the differency between all stations for $\mathrm{PM}_{10}$ concentration. According to the binary comparison, there was statistically signifant difference for $\mathrm{PM}_{10}$ concentrations between the $\mathrm{BV}$ and the $\mathrm{AV}$ : UskudarMecidiyekoy, Sirinevler-Umraniye, Mecidiyekoy-Umraniye stations $(p<0.01)$; Uskudar-Sirinevler, UskudarMecidiyekoy, Sirinevler-Umraniye, Mediyekoy-Umraniye stations $(p<0.05)$ respectively (Table 1$)$.

Table 1: Evaluations of $\mathrm{PM}_{10}$ concentrations during the $\mathrm{BV}$ and during the $\mathrm{AV}$ at all Stations. 


\begin{tabular}{|c|c|c|c|c|}
\hline \multirow[b]{2}{*}{ Stations } & & \multicolumn{2}{|c|}{$\mathrm{PM}_{10}$ concentrations in 2020} & \multirow[b]{2}{*}{${ }^{a} p$} \\
\hline & & BV $(n=44)$ & $\mathrm{AV}(\mathrm{n}=35)$ & \\
\hline \multirow[t]{2}{*}{${ }^{1}$ Uskudar } & Min.-Max.(Median) & $10,4-77,2(40,7)$ & $12,9-116,2(27)$ & $0,019 *$ \\
\hline & Avrg. $\pm S D$ & $40,18 \pm 18,43$ & $31,56 \pm 20,75$ & \\
\hline \multirow[t]{2}{*}{${ }^{2}$ Sirinevler } & Min.-Max.(Median) & $19,9-116,1(43,8)$ & $22,3-131,7(41,8)$ & 0,388 \\
\hline & Avrg. $\pm S D$ & $47,85 \pm 19,56$ & $45,58 \pm 23,57$ & \\
\hline \multirow[t]{2}{*}{${ }^{3}$ Mecidiyeköy } & Min.-Max.(Median) & $22,3-125,5(53,4)$ & $26,6-185,1(51,7)$ & 0,608 \\
\hline & Avrg. $\pm S D$ & $56,25 \pm 20,31$ & $58,47 \pm 35,55$ & \\
\hline \multirow[t]{4}{*}{${ }^{4}$ Umraniye } & Min.-Max.(Median) & $15,6-55,9(30,1)$ & $12,8-83,2(29)$ & 0,395 \\
\hline & Avrg. $\pm S D$ & $32,49 \pm 9,80$ & $32,18 \pm 16,56$ & \\
\hline & ${ }^{b} p$ & $0,001 * *$ & $0,001 * *$ & \\
\hline & ${ }^{c} p_{1-2}$ & 0,321 & $0,010^{*}$ & \\
\hline \multirow[t]{5}{*}{ Binary evaluations between stations } & ${ }^{c} p_{1-3}$ & $0,001 * *$ & $0,001 * *$ & \\
\hline & ${ }^{c} p_{1-4}$ & 0,200 & 1,000 & \\
\hline & ${ }^{c} p_{2-3}$ & 0,263 & 0,810 & \\
\hline & ${ }^{c} p_{2-4}$ & $0,001 * *$ & $0,024^{*}$ & \\
\hline & ${ }^{c} p_{3-4}$ & $0,001^{* *}$ & $0,001^{* *}$ & \\
\hline
\end{tabular}

${ }^{a}$ Mann Whitney U Test

${ }^{* *} p<0.01$
${ }^{b}$ Kruskal Wallis Test

${ }^{*} p<0.05$

${ }^{c}$ Bonferroni Dunn Test

The average $\mathrm{NO}_{2}$ concentration was $41.90 \pm 18.79 \mu \mathrm{g} / \mathrm{m}^{3}$ during the study period at Uskudar station in 2020 (Fig.9). The average $\mathrm{NO}_{2}$ concentrations were $48.12 \pm 18.06 \mu \mathrm{g} / \mathrm{m}^{3}$ and $33.34 \pm 16.47 \mu \mathrm{g} / \mathrm{m}^{3}$ during the $\mathrm{BV}$ and the $\mathrm{AV}$ respectively. Considering to all years the $\mathrm{NO}_{2}$ concentration during the $\mathrm{AV}$ was higher than the BV, except 2020. In addition, the minimum temperature was observed in 2020, which in turn expectation of high $\mathrm{NO}_{2}$ concentration, the minimum $\mathrm{NO}_{2}$ concentration was seen during the $\mathrm{AV}$ in 2020 . This result exhibits that precautions taken for COVID-19 epidemic had positive effects on air quality. Hence, significant difference was seen for $\mathrm{NO}_{2}$ concentrations between the $\mathrm{BV}$ and the $\mathrm{AV}$ in 2020 , statistically $(p=0.001 ; p<0.01)$ (Table 2$)$.

The average $\mathrm{NO}_{2}$ concentration was $62.96 \pm 23.71 \mu \mathrm{g} / \mathrm{m}^{3}$ during the study period at Sirinevler station in 2020 (Fig.10). The average concentration was identified as $50.05 \pm 21.13 \mu \mathrm{g} / \mathrm{m}^{3}$ during the AV, while it was $72.94 \pm 20.75 \mu \mathrm{g} / \mathrm{m}^{3}$ during the BV. Except 2018 , the $\mathrm{NO}_{2}$ concentration during the $\mathrm{BV}$ was higher than the $\mathrm{AV}$ among all years. Although 2020 had the minimum temperature in five years, the difference of $\mathrm{NO}_{2}$ concentrations between the BV and the $\mathrm{AV}$ was maximum level in 2020. The positive contribution of precautions taken for COVID-19 was clearly seen. Statistically significant difference for this pollutant during the BV and the $A V(p=0.001 ; p<0.01)$ supports these comments (Table 2).

The average $\mathrm{NO}_{2}$ concentration was $44.41 \pm 15.35 \mu \mathrm{g} / \mathrm{m}^{3}$ during the study period at Mecidiyekoy station in 2020 (Fig.11). While the average $\mathrm{NO}_{2}$ concentration was $48.79 \pm 16.05 \mu \mathrm{g} / \mathrm{m}^{3}$ during the $\mathrm{BV}$, it was $39.52 \pm 13.09 \mu \mathrm{g} / \mathrm{m}^{3}$ during the AV. Contrary to other years, the average $\mathrm{NO}_{2}$ concentration during the AV was lower than the BV in 2020. This situation indicates the results of the prevention taken for COVID-19 
on air quality are positive. In addition, there was statistically significant difference for $\mathrm{NO}_{2}$ concentration between the BV and the AV ( $p=0.02 ; p<0.05)$ supports this comment (Table 2$)$.

The average $\mathrm{NO}_{2}$ concentration was $53.36 \pm 14.04 \mu \mathrm{g} / \mathrm{m}^{3}$ during the study period in 2020 . While the average $\mathrm{NO}_{2}$ concentration during the $\mathrm{AV}\left(47.08 \pm 11.58 \mu \mathrm{g} / \mathrm{m}^{3}\right)$ was lower than the $\mathrm{BV}(57.99 \pm 14.01$ $\mu \mathrm{g} / \mathrm{m}^{3}$ ) (Fig.12). Although, the average $\mathrm{NO}_{2}$ concentration during the $\mathrm{BV}$ was higher than the $\mathrm{AV}$ comparing to all years. Due to COVID-19 outbreak, $\mathrm{NO}_{2}$ concentration during the AV was lower than the BV in 2020. This situation shows the success of social isolation to prevent COVID-19 pandemic, also statistically supported $(p=0.002 ; p<0.01)$ (Table 2).

The average $\mathrm{NO}_{2}$ concentrations of Istanbul were detected using the data from Uskudar, Sirinevler, Mecidiyekoy and Umraniye stations, in Fig. 13. The average $\mathrm{NO}_{2}$ concentration was $50.82 \pm 15.65 \mu \mathrm{g} / \mathrm{m}^{3}$ during the study period in 2020. Unlike other years, the average $\mathrm{NO}_{2}$ concentration during the BV $\left(57.61 \pm 13.20 \mu \mathrm{g} / \mathrm{m}^{3}\right)$ was higher than the $\mathrm{AV}\left(42.03 \pm 14.68 \mu \mathrm{g} / \mathrm{m}^{3}\right)$, in 2020. This result illustrates the positive effect of COVID-19 pandemic on air quality, also statistically supported $(p=0.001 ; p<0.01)$ (Table 2).

The statistically significant difference was seen in the $\mathrm{NO}_{2}$ concentrations at all stations (for Uskudar, Sirinevler and Umraniye $\mathrm{p}<0.01$; for Mecidiyekoy $\mathrm{p}<0.05$ ) during the BV and the AV. The group that creates the difference of $\mathrm{NO}_{2}$ concentration between the $\mathrm{BV}$ and $\mathrm{AV}$ were detected by binary comparison.

According to binary comparison, there was statistically signifant difference between Uskudar-Sirinevler, Sirinevler-Mecidiyekoy, Mecidiyekoy-Umraniye ( $p<0.01)$; Uskudar-Sirinevler, Uskudar-Umraniye stations $(p<0.01)$ during the BV and the AV, respectively (Table 2$)$.

Table 2: Evaluation of $\mathrm{NO}_{2}$ Concentrations in the $\mathrm{BV}$ and in the $\mathrm{AV}$ at all Stations.

\begin{tabular}{|c|c|c|c|c|}
\hline \multirow[t]{2}{*}{ Stations } & & \multicolumn{2}{|c|}{$\mathrm{NO}_{2}$ concentrations in 2020} & \multirow[t]{2}{*}{${ }^{a} p$} \\
\hline & & BV $(n=44)$ & $\mathrm{AV}(\mathrm{n}=35)$ & \\
\hline \multirow[t]{2}{*}{${ }^{1}$ Uskudar } & Min.-Max.(Median) & $15,9-92,8(46,3)$ & $9-67,6(25,7)$ & $0,001 * *$ \\
\hline & Avrg. $\pm S D$ & $48,12 \pm 18,06$ & $33,34 \pm 16,47$ & \\
\hline \multirow[t]{2}{*}{${ }^{2}$ Sirinevler } & Min.-Max.(Median) & $33,9-122(68,6)$ & $18,9-99,4(41,6)$ & $0,001 * *$ \\
\hline & Avrg. $\pm S D$ & $72,94 \pm 20,75$ & $50,05 \pm 21,13$ & \\
\hline \multirow[t]{2}{*}{${ }^{3}$ Mecidiyekoy } & Min.-Max.(Median) & $20,7-75,9(53,1)$ & $16,9-67,5(35,4)$ & $0,020 *$ \\
\hline & $A v r g . \pm S D$ & $48,79 \pm 16,05$ & $39,52 \pm 13,09$ & \\
\hline \multirow[t]{4}{*}{${ }^{4}$ Umraniye } & Min.-Max.(Median) & $29,4-86,3(55,3)$ & $23,2-69,3(47,8)$ & $0,002 * *$ \\
\hline & $A v r g . \pm S D$ & $57,99 \pm 14,01$ & $47,08 \pm 11,58$ & \\
\hline & ${ }^{b} p$ & $0,001 * *$ & $0,001 * *$ & \\
\hline & ${ }^{c} p_{1-2}$ & $0,001 * *$ & $0,003 * *$ & \\
\hline \multirow[t]{5}{*}{ Binary evaluations between stations } & ${ }^{c} p_{1-3}$ & 1,000 & 0,815 & \\
\hline & ${ }^{c} p_{1-4}$ & 0,099 & $0,003^{* *}$ & \\
\hline & ${ }^{c} p_{2-3}$ & $0,001 * *$ & 0,254 & \\
\hline & ${ }^{c} p_{2-4}$ & $0,009 * *$ & 1,000 & \\
\hline & ${ }^{c} p_{3-4}$ & 0,371 & 0,214 & \\
\hline
\end{tabular}

${ }^{a}$ Mann Whitney UTest $\quad{ }^{b}$ Kruskal Wallis Test $\quad{ }^{c}$ Bonferroni Dunn Test
${ }^{* *} p<0.01 \quad 0.05$ 
According to the related regulation (RAQAM) in Turkey and EU Directive, 24h averages of $\mathrm{PM}_{10}$ and $1 \mathrm{~h}$ averages of $\mathrm{NO}_{2}$ limit values are $50 \mu \mathrm{g} / \mathrm{m}^{3}$ and $200 \mu \mathrm{g} / \mathrm{m}^{3}$ respectively. $24 \mathrm{~h}$ averages $\mathrm{PM}_{10}$ limit was exceeded 3 times during the AV-9 times during the BV at Uskudar station, 10 times during the AV- 12 times during the BV at Sirinevler station, 16 times during the AV-21 times during the AV at Mecidiyekoy station, 4 times during the AV-2 times during the BV at Umraniye station. The number of days that cannot be measured $\mathrm{PM}_{10}$ concentration were $6,0,4,1$ day during the $\mathrm{AV}$ and 1, 0, 10, 3 during the BV at Uskudar, Sirinevler, Mecidiyekoy and Umraniye stations respectively. The $\mathrm{NO}_{2}$ concentrations $1 \mathrm{~h}$ averages were exceeded only once at Sirinevler station among all stations. The number of days that cannot be measured for $\mathrm{NO}_{2}$ concentration were $3,1,1,4$ days during the $\mathrm{AV}$ and $0,0,6,2$ during the $\mathrm{BV}$ at Uskudar, Sirinevler, Mecidiyekoy and Umraniye stations respectively.

\section{Conclusion}

In this study, the effect of social isolation due to the COVID-19 pandemic at monitoring 4 stations located close to road traffic on air quality was examined between the period of 01.02-19.04 in 2016-2020. Air quality assessment for Istanbul was carried out in two period: before and after the date of the first death from COVID-19 in Turkey. Also, $\mathrm{PM}_{10}$ and $\mathrm{NO}_{2}$ concentrations in these periods were compared within 2016-2020.

Results obtained from the presents study can be aligned in the following:

- There was no significant decrease for the average $\mathrm{PM}_{10}$ concentration in İstanbul between the BV and $A V$ in 2020. However, the $\mathrm{PM}_{10}$ concentrations remained either constant or even slightly increased during the study period at these stations. Hence, it can be stated that $\mathrm{PM}_{10}$ concentration is not only affected by the traffic, but also affected by fossil-fuel heating, agriculture, landfills, wildfires and industrial sources.

- There was no statistically significant difference between $\mathrm{PM}_{10}$ concentration and temperature at all stations during the AV and the BV in 2020.

- While a significant difference for $\mathrm{PM}_{10}$ concentration was observed only at Uskudar station, a significant difference was observed at all stations for $\mathrm{NO}_{2}$ pollutants between the $\mathrm{BV}$ and the $\mathrm{AV}$ $\left(\mathrm{PM}_{10}\right.$ and $\mathrm{NO}_{2}$ concentration during the $\left.\mathrm{AV}<\mathrm{BV}\right)$ in 2020.

- $\mathrm{NO}_{2}$ concentration in the $\mathrm{AV}$ are much lower than the $\mathrm{BV}$ in 2020, among all years. The observed decline in $\mathrm{NO}_{2}$ is in agreement with the reduction of $\mathrm{NO}_{2}$ emissions from COVID-19 outbreak.

As a result of the precaution taken for COVID-19, the concentration of $\mathrm{NO}_{2}$, one of the most important air pollutants, decreased by 11.8 percent. If $\mathrm{NO}_{2}$ concentration which was obtained during the $\mathrm{AV}$, can be kept constant in the future, the rate of deaths and diseases caused by air pollution may decrease by 10 
percent. Hence, it is necessary to supply continuity of the measures taken for COVID-19, to increase the level of air quality for a healthy future and avoiding new pandemic.

\section{Declarations}

\section{Conflicts of interest/Competing interests:}

The authors declare that they have no known competing financial interests or personal relationships that could have appeared to influence the work reported in this paper.

\section{References}

1. Coronavirus disease 2019 (COVID-19) situation report-85. World Health Organization website. https://www.who.int/docs/default-source/coronaviruse/situation-reports/20200421-sitrep-92-covid19.pdf?sfvrsn=38e6b06d_4. Published april 21, 2020. Accessed April 22, 2020.

2. COVID-19 situation report for Turkey, Republic of Turkey Ministry of Health website, https://covid19.saglik.gov.tr/ published april 21, 2020. Accessed April 22, 2020.

3. Paramati, S. R., Ozturk, I., Bhattacharya, S. (2016). The effect of renewable energy consumption on economic growth: Evidence from top 38 countries. Applied Energy, 162, 733-741.

4. Saidi, K., Omri, A. (2020). The impact of renewable energy on carbon emissions and economic growth in 15 major renewable energy-consuming countries. Environmental Research, 109567.

5. Dutta, T., Kim, K. H., Uchimiya, M., Kwon, E. E., Jeon, B. H., Deep, A., Yun, S. T. (2016). Global demand for rare earth resources and strategies for green mining. Environmental Research, 150, 182-190.

6. WHO, First WHO Global Conference on Air Pollution and Health, World Health Organization website. https://www.who.int/airpollution/events/conference/en/. 30 October - 1 November 2018. Accessed April 10, 2020.

7. Croft, D., Rich, D. Q., Hopke, P. K., Thevenet-Morrison, K., Thurston, S. W., Georas, S. N., Falsey, A. (2019). Risk of Influenza and Respiratory Syncytial Virus Infection Associated with Particulate Air Pollution: An Adult Case-Control Study. in d26. Health effects associated with indoor and outdoor air pollution. American Thoracic Society, A6020.

8. Rodrigues, A. F., Santos, A. M., Ferreira, A. M., Marino, R., Barreira, M. E., Cabeda, J. M. (2019). YearLong Rhinovirus Infection is Influenced by Atmospheric Conditions, Outdoor Air Virus Presence, and Immune System-Related Genetic Polymorphisms. Food and environmental virology, 11(4), 340-349.

9. Yu, Y., Yu, Z., Sun, P., Lin, B., Li, L., Wang, Z., Guo, S. (2018). Effects of ambient air pollution from municipal solid waste landfill on children's non-specific immunity and respiratory health. Environmental Pollution, 236, 382-390.

10. Morawska, L., Thomas, S., Jamriska, M., Johnson, G. (1999). The modality of particle size distributions of environmental aerosols. Atmospheric Environment, 33(27), 4401-4411.

11. Brunekreef, B., Holgate, S. T. (2002). Air pollution and health. The lancet, 360(9341), 1233-1242. 
12. Finkelstein, M., Jerrett, M., DeLuca, P., Finkelstein, N., Verma, D. K., Chapman, K., Sears, M. R. (2003). A cohort study of income, air pollution and mortality. Can Med Assoc J, 169, 397-402.

13. Nafstad, P., Håheim, L. L., Wisløff, T., Gram, F., Oftedal, B., Holme, I., Leren, P. (2004). Urban air pollution and mortality in a cohort of Norwegian men. Environmental health perspectives, 112(5), 610-615.

14. Janssen, N. A. H., Fischer, P., Marra, M., Ameling, C., Cassee, F. R. (2013). Short-term effects of PM2. 5, PM10 and PM2. 5-10 on daily mortality in the Netherlands. Science of the Total Environment, 463, 20-26.

15. Kan, H., London, S. J., Chen, G., Zhang, Y., Song, G., Zhao, N., Chen, B. (2007). Differentiating the effects of fine and coarse particles on daily mortality in Shanghai, China. Environment international, 33(3), 376-384.

16. Namdeo, A., Bell, M. C. (2005). Characteristics and health implications of fine and coarse particulates at roadside, urban background and rural sites in UK. Environment International, 31(4), 565-573.

17. Davidson, C. I., Phalen, R. F., Solomon, P. A. (2005). Airborne particulate matter and human health: a review. Aerosol Science and Technology, 39(8), 737-749.

18. Liu, E., Yan, T., Birch, G., Zhu, Y. (2014). Pollution and health risk of potentially toxic metals in urban road dust in Nanjing, a mega-city of China. Science of the Total Environment, 476, 522-531.

19. Turner, M. C., Krewski, D., Pope III, C. A., Chen, Y., Gapstur, S. M., Thun, M. J. (2011). Long-term ambient fine particulate matter air pollution and lung cancer in a large cohort of neversmokers. American journal of respiratory and critical care medicine, 184(12), 1374-1381.

20. Dorevitch, S., Demirtas, H., Perksy, V. W., Erdal, S., Conroy, L., Schoonover, T., Scheff, P. A. (2006). Demolition of high-rise public housing increases particulate matter air pollution in communities of high-risk asthmatics. Journal of the Air \& Waste Management Association, 56(7), 1022-1032.

21. Eggleston, P. A., Buckley, T. J., Breysse, P. N., Wills-Karp, M., Kleeberger, S. R., \& Jaakkola, J. J. (1999). The environment and asthma in US inner cities. Environmental Health Perspectives, 107(suppl 3), 439-450.

22. Spencer-Hwang, R., Knutsen, S. F., Soret, S., Ghamsary, M., Beeson, W. L., Oda, K., Jaipaul, N. (2011). Ambient air pollutants and risk of fatal coronary heart disease among kidney transplant recipients. American journal of kidney diseases, 58(4), 608-616.

23. Ergenekon P., Ulutaş, K. (2013). Heavy metal content of total suspended air particles in the heavily industrialized town of Gebze, Turkey. Bulletin of Environmental Contamination and Toxicology, 92, 90-95.

24. Peng, R. D., Bell, M. L., Geyh, A. S., McDermott, A., Zeger, S. L., Samet, J. M., Dominici, F. (2009). Emergency admissions for cardiovascular and respiratory diseases and the chemical composition of fine particle air pollution. Environmental health perspectives, 117(6), 957-963.

25. Bell, M. L., Ebisu, K., Peng, R. D., Samet, J. M., Dominici, F. (2009). Hospital admissions and chemical composition of fine particle air pollution. American journal of respiratory and critical care medicine, 179(12), 1115-1120. 
26. Schwarze, P. E., Øvrevik, J., Låg, M., Refsnes, M., Nafstad, P., Hetland, R. B., Dybing, E. (2006). Particulate matter properties and health effects: consistency of epidemiological and toxicological studies. Human \& experimental toxicology, 25(10), 559-579.

27. Deng, Q., Deng, L., Lu, C., Li, Y., Norbäck, D. (2018). Parental stress and air pollution increase childhood asthma in China. Environmental research, 165, 23-31.

28. Deng, Q., Lu, C., Li, Y., Sundell, J., Norbäck, D. (2016). Exposure to outdoor air pollution during trimesters of pregnancy and childhood asthma, allergic rhinitis, and eczema. Environmental research, $150,119-127$.

29. Katanoda, K., Sobue, T., Satoh, H., Tajima, K., Suzuki, T., Nakatsuka, H., Tominaga, S. (2011). An association between long-term exposure to ambient air pollution and mortality from lung cancer and respiratory diseases in Japan. Journal of epidemiology, 1102090211-1102090211.

30. Lipsett, M. J., Ostro, B. D., Reynolds, P., Goldberg, D., Hertz, A., Jerrett, M., Bernstein, L. (2011). Longterm exposure to air pollution and cardiorespiratory disease in the California teachers study cohort. American journal of respiratory and critical care medicine, 184(7), 828-835.

31. Mills, I. C., Atkinson, R. W., Kang, S., Walton, H., Anderson, H. R. (2015). Quantitative systematic review of the associations between short-term exposure to nitrogen dioxide and mortality and hospital admissions. BMJ open, 5(5), e006946.

32. Pierangeli, I., Nieuwenhuijsen, M. J., Cirach, M., Rojas-Rueda, D. (2020). Health equity and burden of childhood asthma-related to air pollution in Barcelona. Environmental Research, 109067.

33. Ogen, Y. (2020). Assessing nitrogen dioxide (NO2) levels as a contributing factor to the coronavirus (COVID-19) fatality rate. Science of The Total Environment, 726, 138605.

34. Republic of Turkey Ministry of Environment And Urbanization website, https://sim.csb.gov.tr/STN/STN_Report/StationDataDownloadNew. Accessed April 21, 2020.

35. Provincial statistics indicators database, Turkish Statistical Institute website, https://biruni.tuik.gov.tr/ilgosterge/?locale=tr. Accessed April 21, 2020.

\section{Figures}




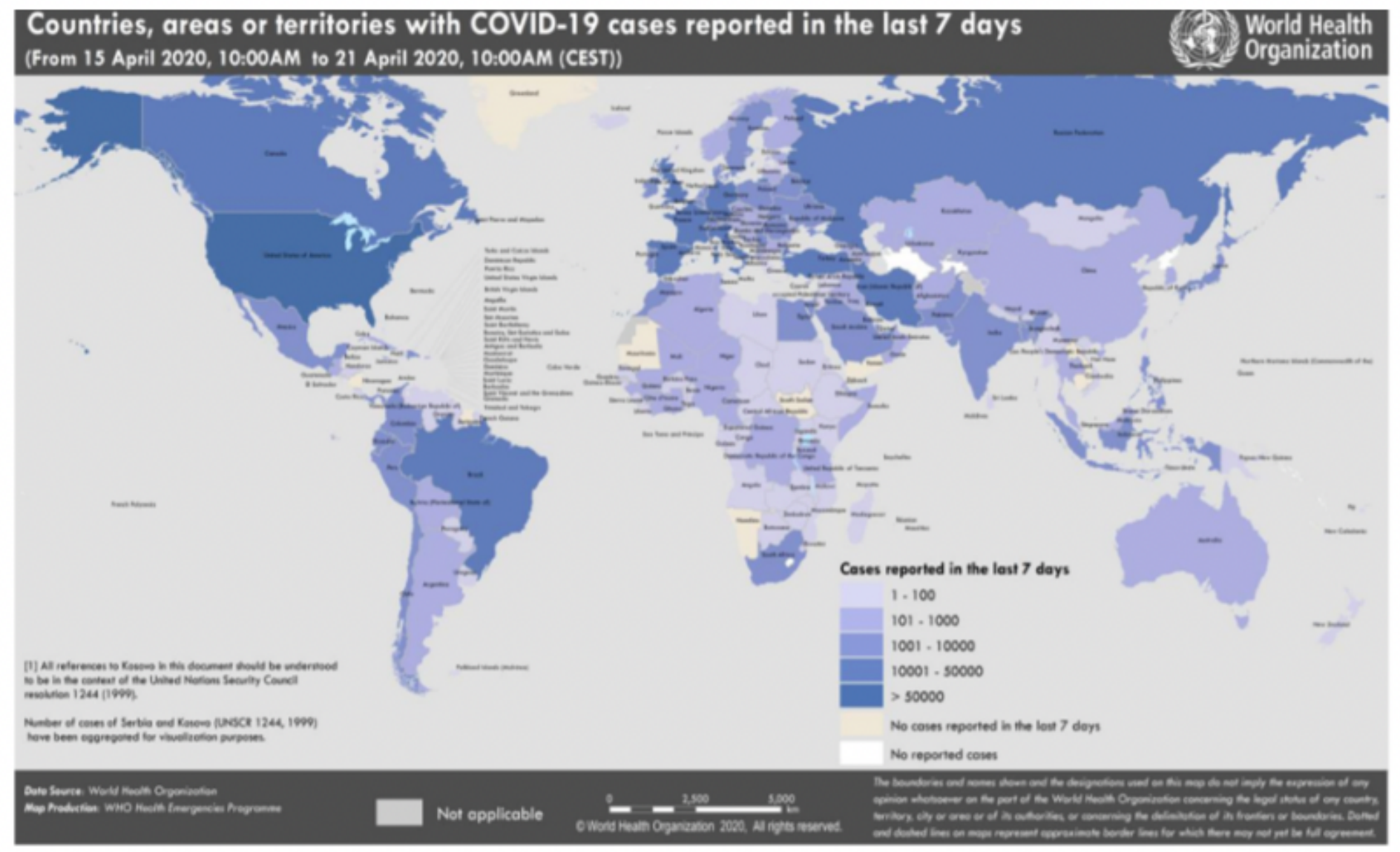

\section{Figure 1}

Countries, territories or areas with reported confirmed cases of COVID-19, 21 April 2020 [1]. Note: The designations employed and the presentation of the material on this map do not imply the expression of any opinion whatsoever on the part of Research Square concerning the legal status of any country, territory, city or area or of its authorities, or concerning the delimitation of its frontiers or boundaries. This map has been provided by the authors. 


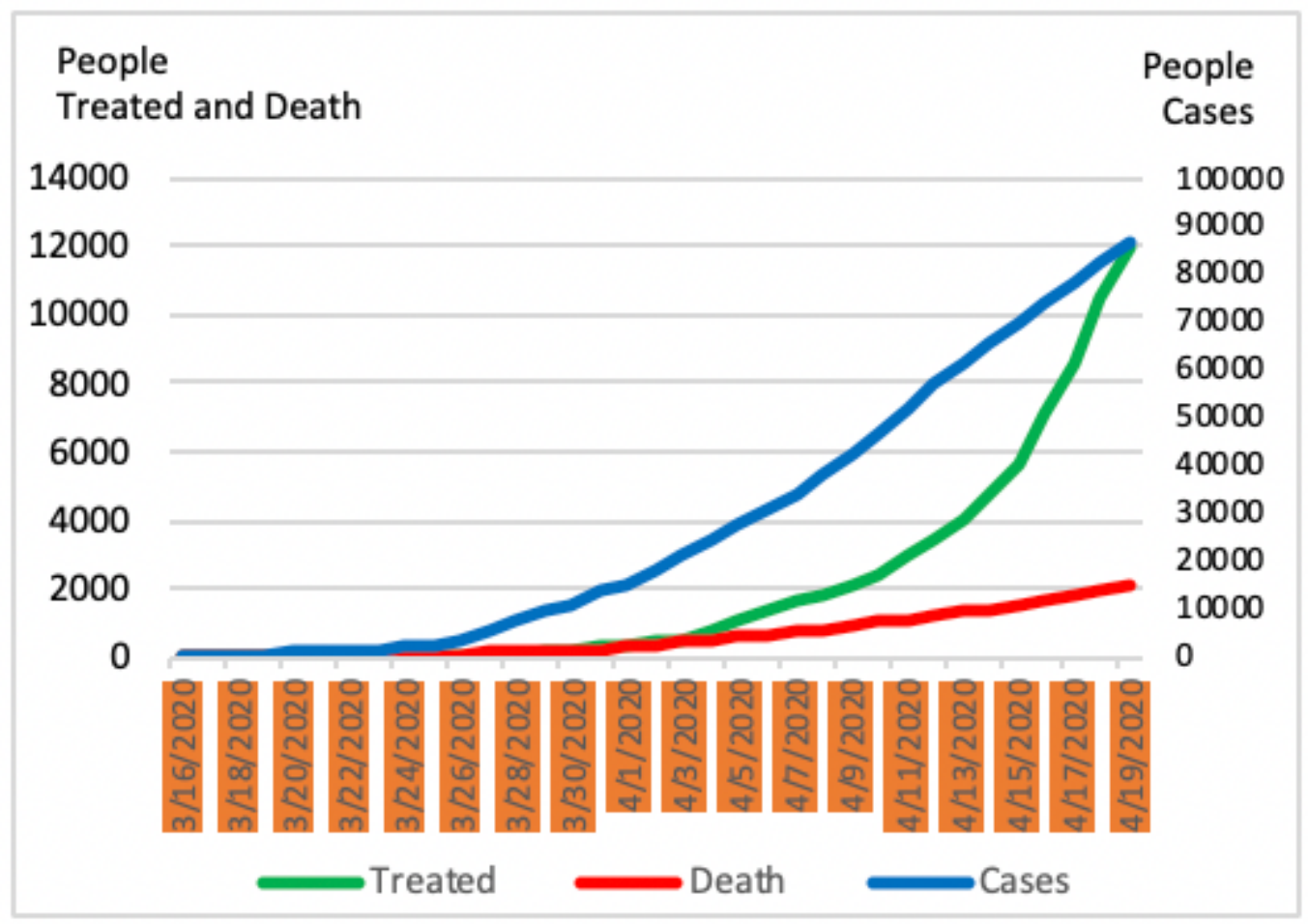

Figure 2

The numerical information COVID-19 in Turkey, 16.03-19.04.2020 [2].

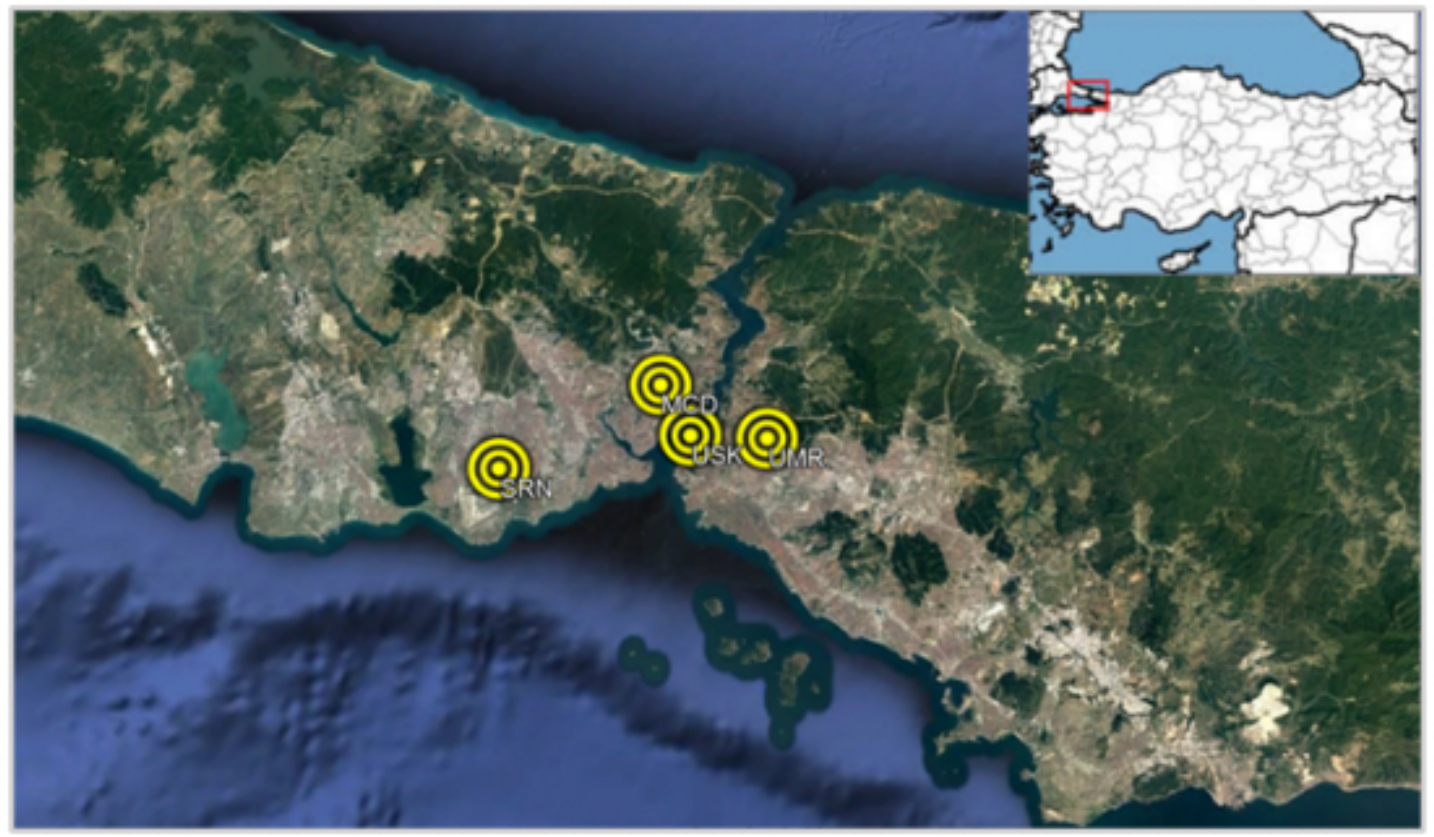

Figure 3

Location of Air Quality Monitoring Stations. 


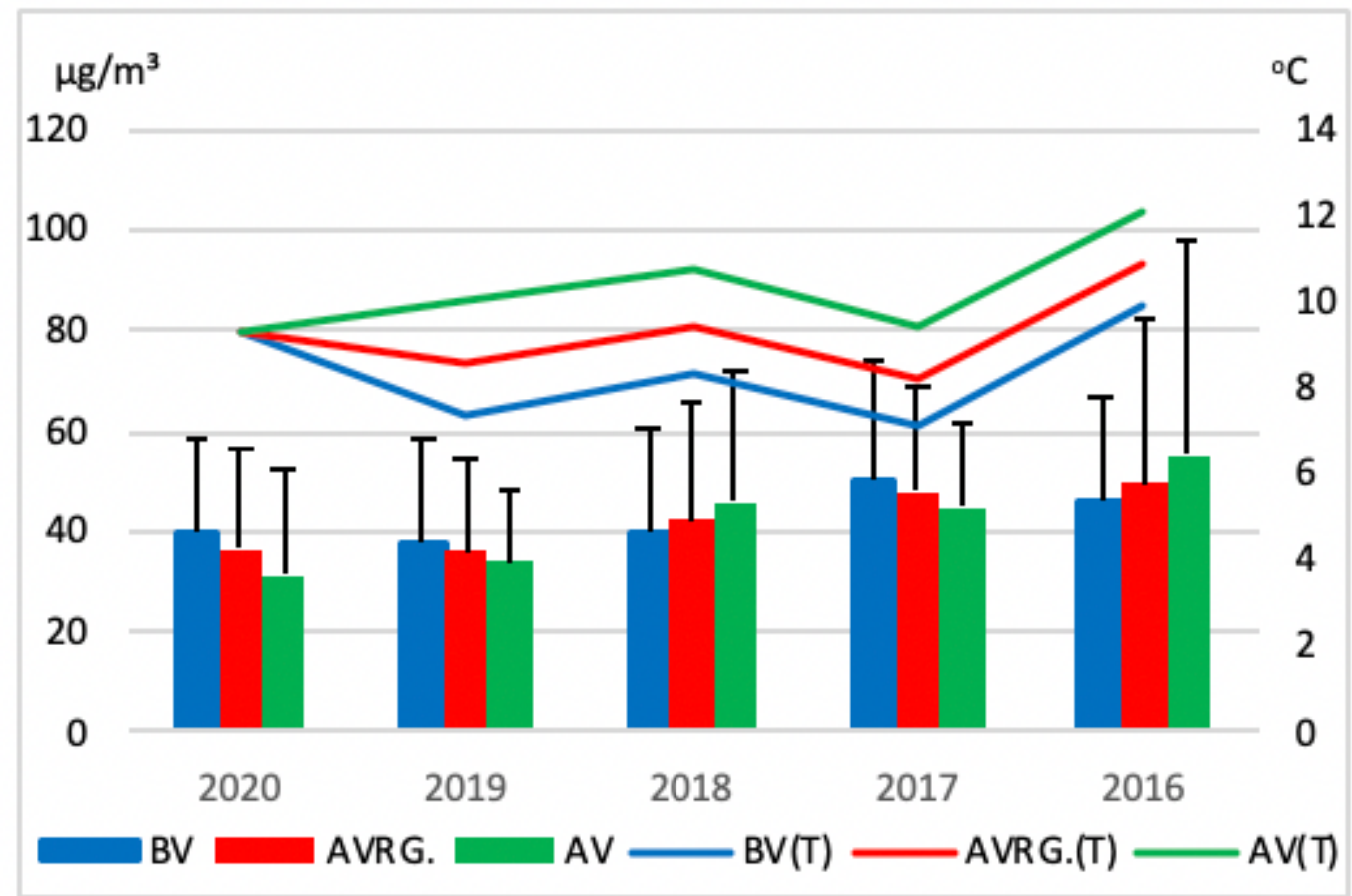

Figure 4

Average Temperature (T), PM10 concentrations and Standard Deviation (SD) (indicated by error bars) during the BV, in the study period and during the AV at Uskudar station.

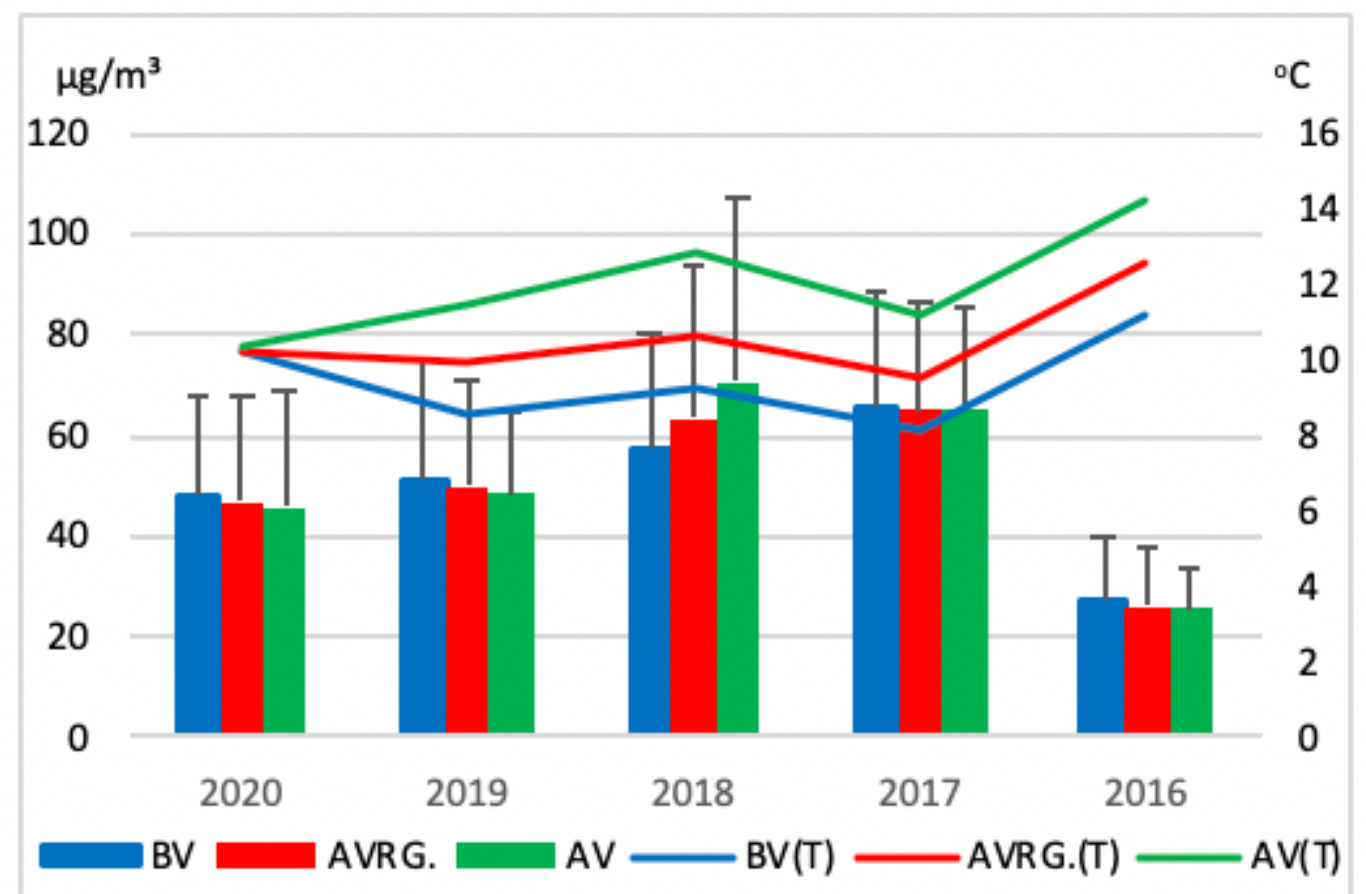

Figure 5 
Average Temperature (T), PM10 concentrations and SD (indicated by error bars) in the BV, in the study period and in the AV at Sirinevler station.

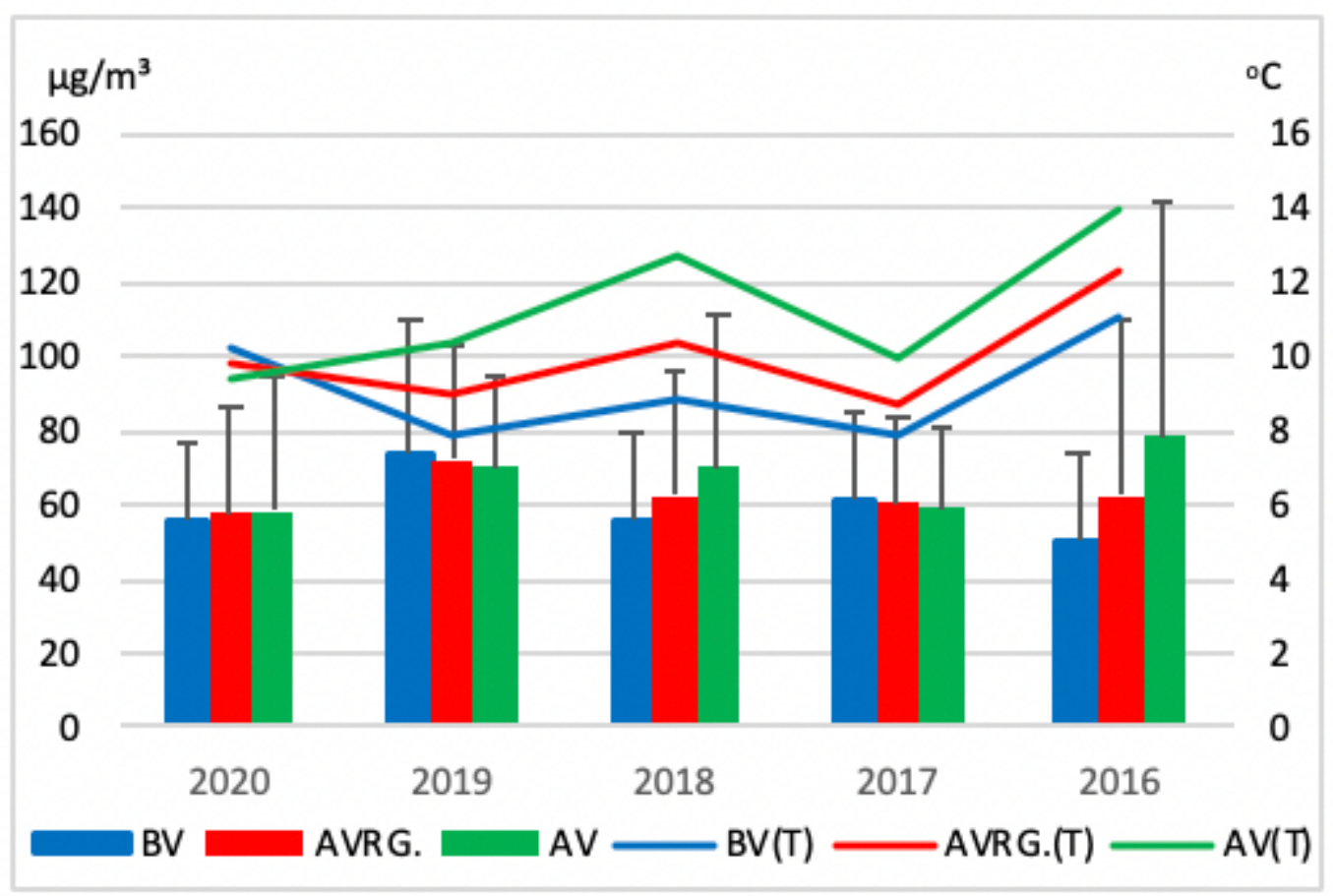

Figure 6

Average Temperature (T), PM10 concentrations and SD (indicated by error bars) during the BV, in the study period and during the AV at Mecidiyekoy station.

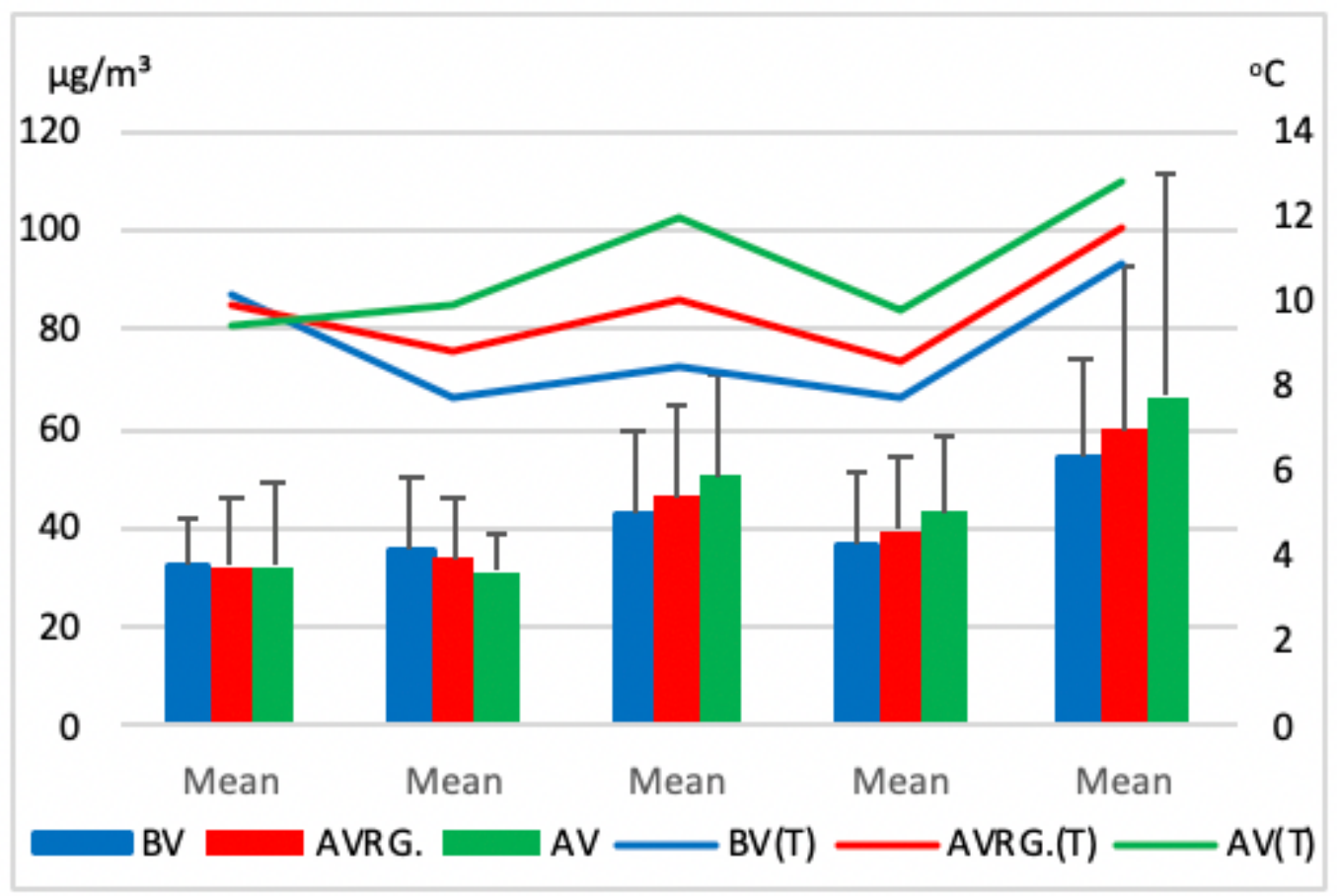

Figure 7 
Average Temperature (T), PM10 concentrations and SD (indicated by error bars) during the BV, in the study period and during the AV at Umraniye station.

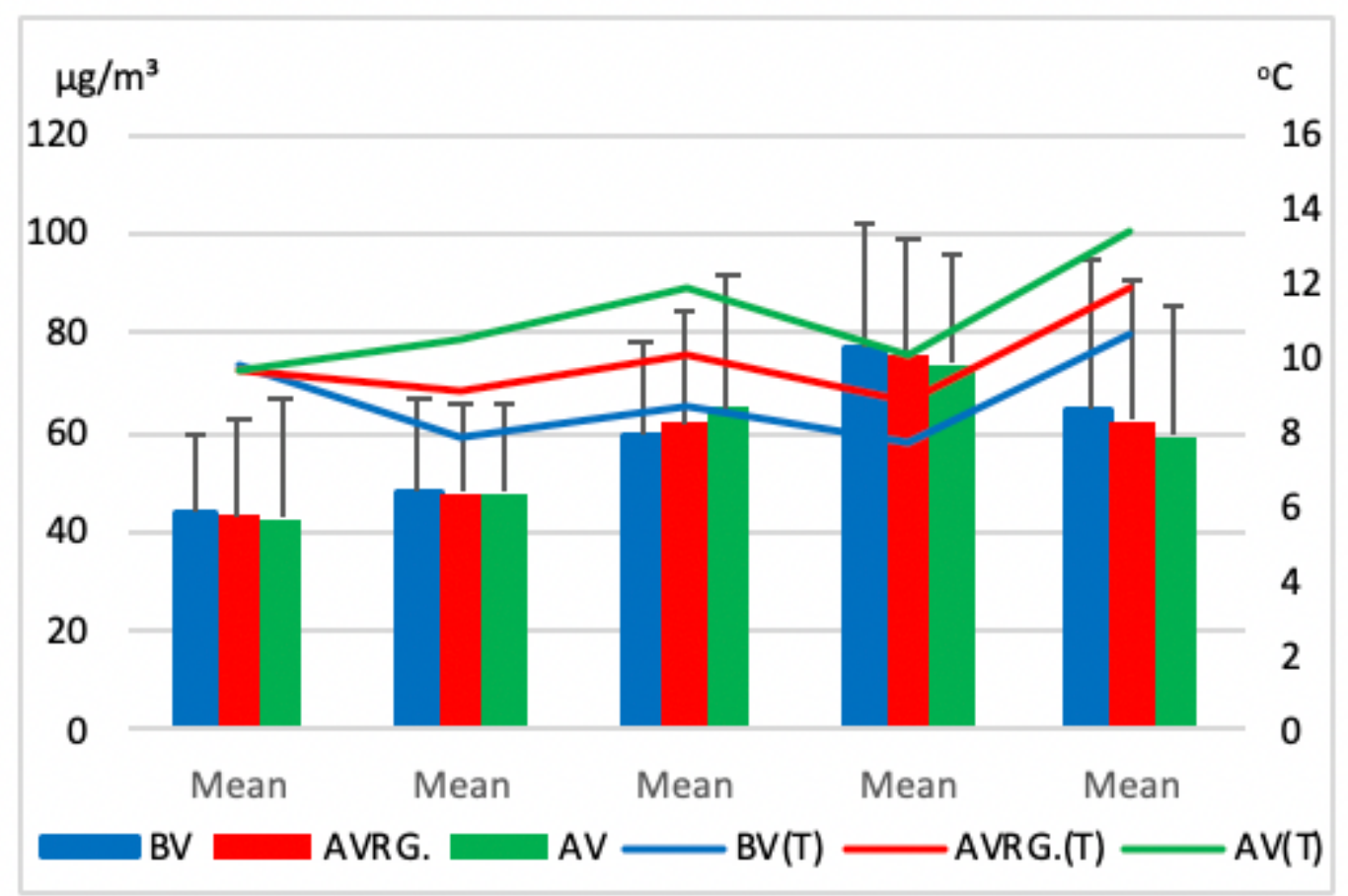

Figure 8

Average Temperature (T), PM10 concentrations and SD (indicated by error bars) in the BV, in the study period and in the AV for Istanbul.

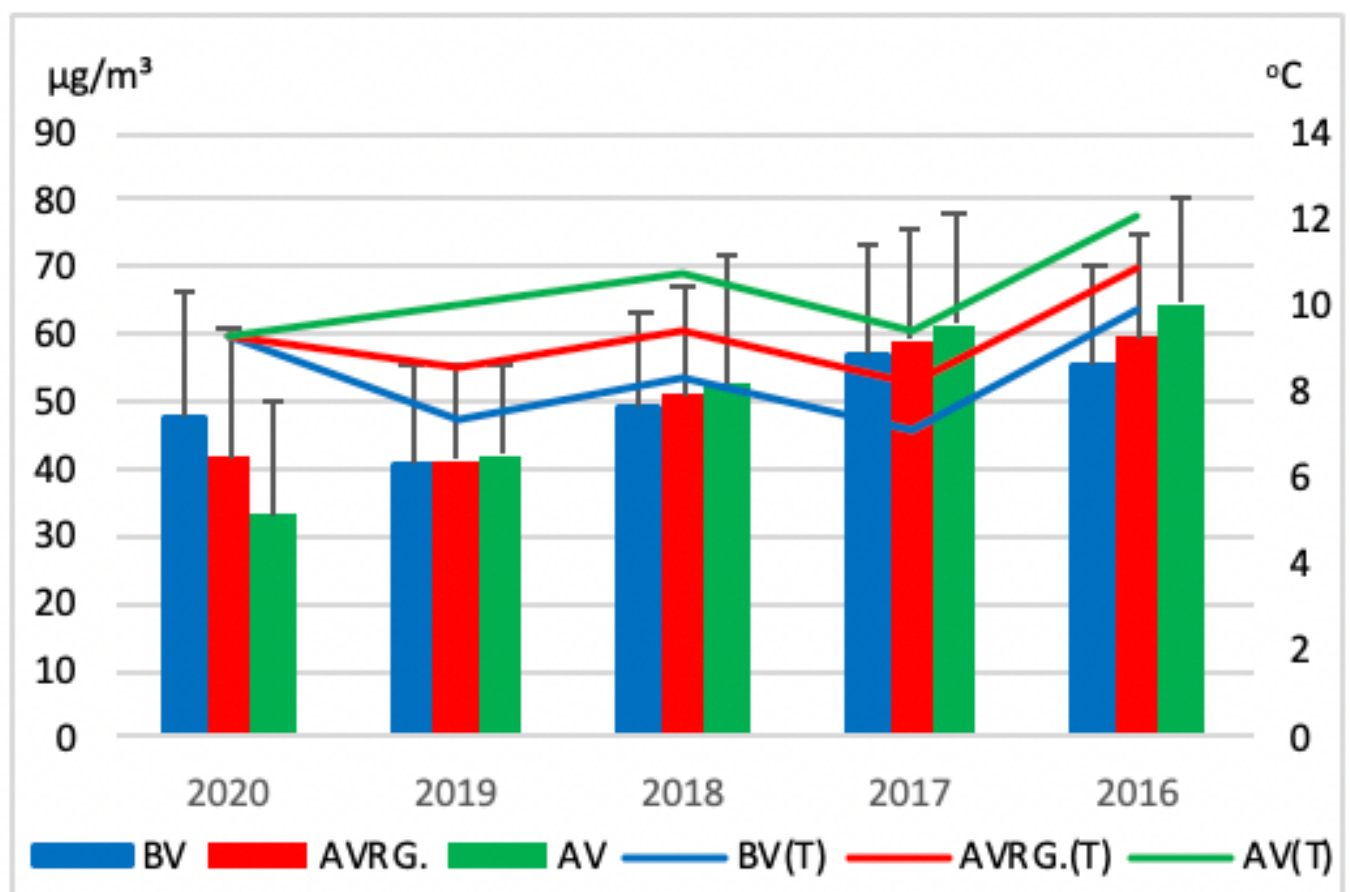

Figure 9 
Average Temperature (T), NO2 concentrations and SD (indicated by error bars) during the BV, in the study period and during the $\mathrm{AV}$ at Uskudar station.

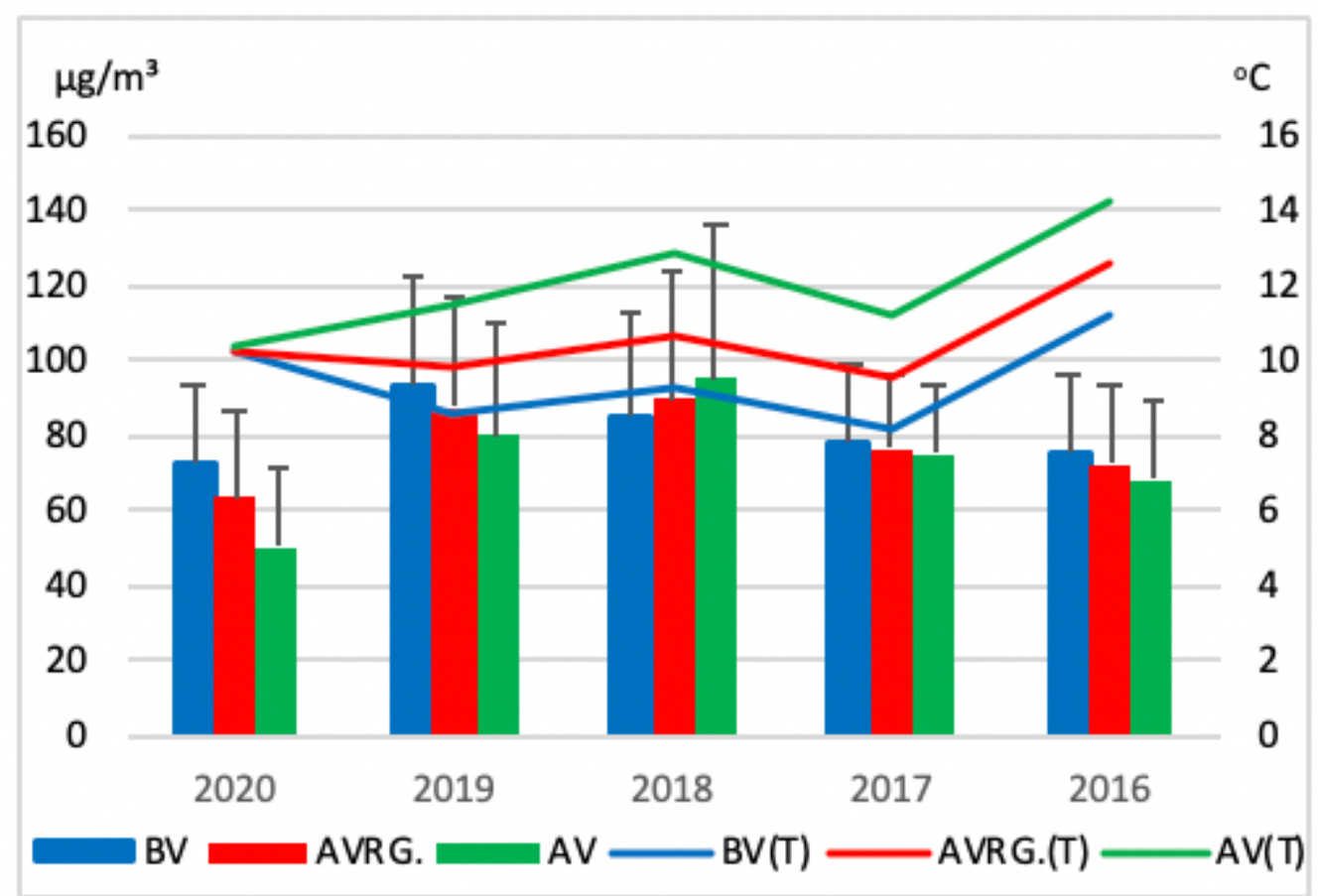

Figure 10

Average Temperature (T), NO2 concentrations and SD (indicated by error bars) in the BV, in the study period and in the AV at Sirinevler station.

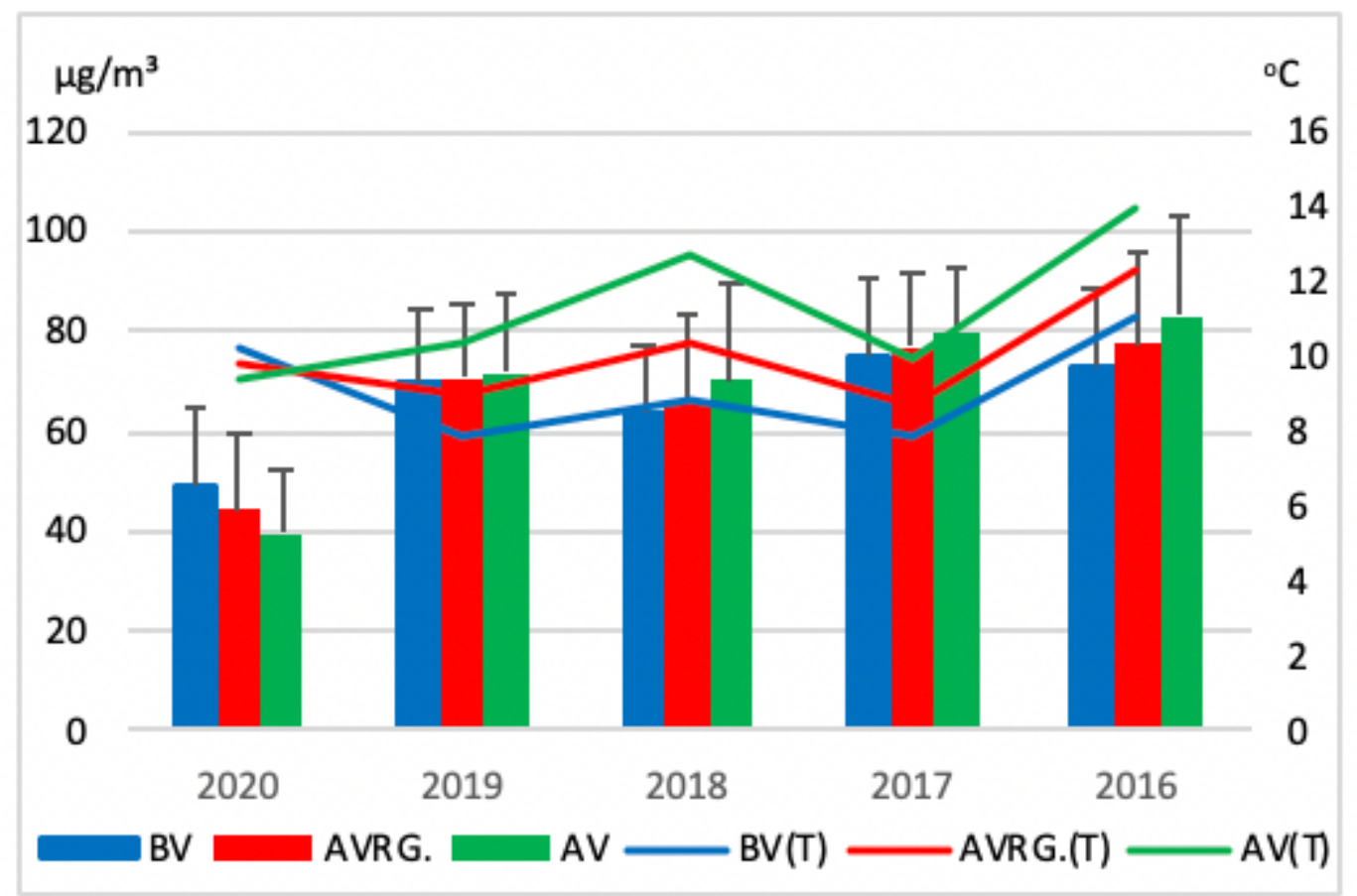




\section{Figure 11}

Average Temperature (T), NO2 concentrations and SD (indicated by error bars) during the BV, in the study period and during the $\mathrm{AV}$ at Sirinevler station.

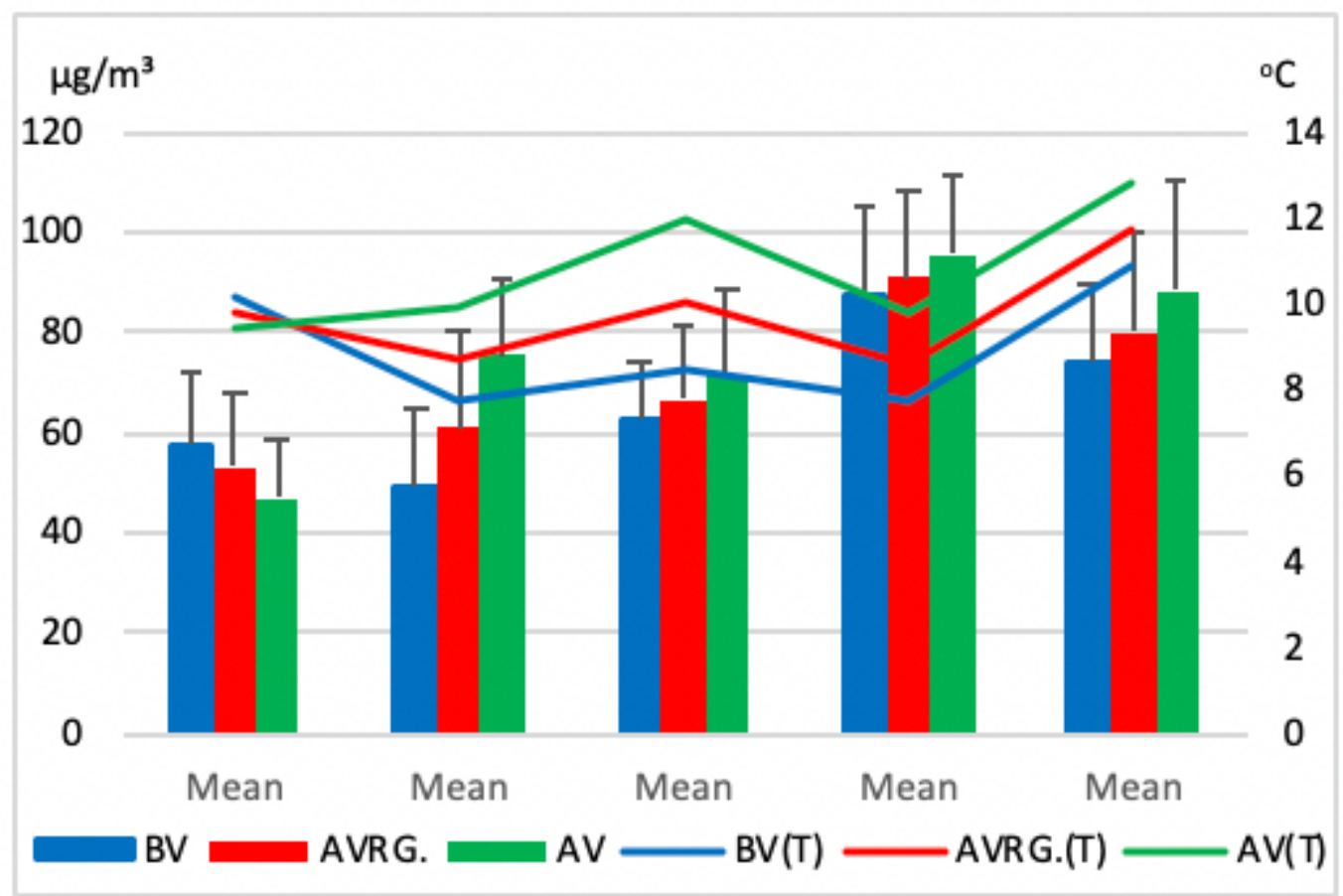

\section{Figure 12}

Average Temperature (T), NO2 concentrations and SD (indicated by error bars) during the BV, in the study period and during the $\mathrm{AV}$ at Umraniye station. 


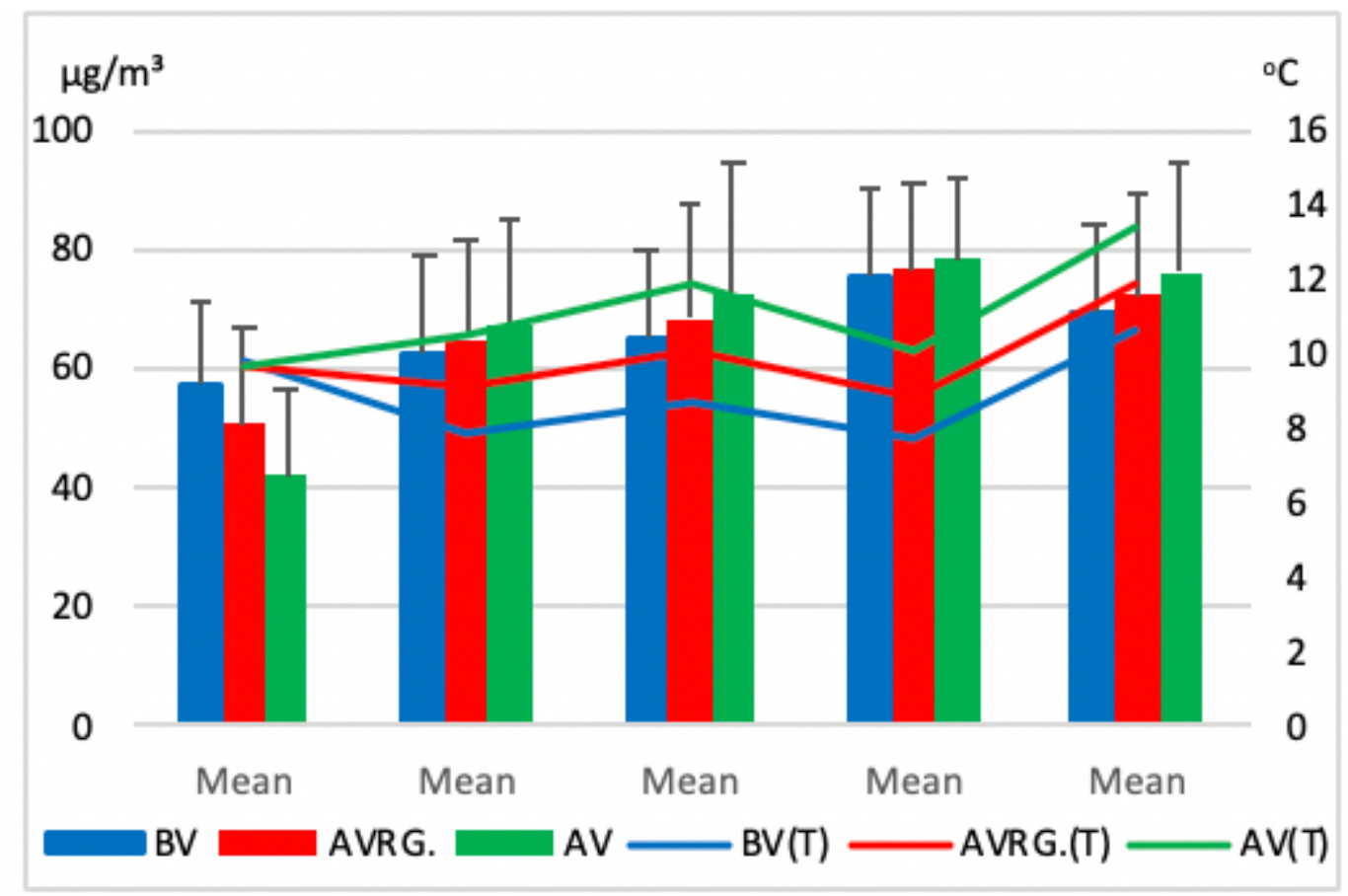

Figure 13

Average Temperature (T), NO2 concentrations and SD (indicated by error bars) during the BV, in the study period and during the AV for Istanbul. 